\title{
Effects of intermittent hypoxia on pulmonary haemodynamics: animal models versus
} studies in humans

\section{J. Zieliński}

ABSTRACT: The aim of this review was to analyse the effects of intermittent hypoxia (IH) on pulmonary haemodynamics, comparing results of animal experiments with results of clinical studies.

In animal investigations even short hypoxic exposure, continuously or in short repeated episodes mimicking obstructive sleep apnoea (OSA), leads to pulmonary artery remodelling and to pulmonary hypertension (PH). Results of investigations on effects of nocturnal IH on pulmonary haemodynamics in patients with chronic obstructive pulmonary disease (COPD) are discordant. Earlier studies reported the development of mild PH in subjects desaturating during sleep, while more recent investigations did not confirm those findings.

Alveolar IH developing during apnoeic episodes during sleep in OSA patients is a diseaseinduced model to study its effects on pulmonary haemodynamics. In the majority of studies in OSA patients pulmonary arterial pressure remained within normal values. $\mathrm{PH}$ was found in patients with OSA accompanied by COPD and/or extreme obesity.

People commuting between lowland and high altitude due to their employment, are also repeatedly exposed to $\mathrm{IH}$. Results of clinical investigations suggest that it did not lead to the development of permanent $\mathrm{PH}$.

The mechanisms of discrepancies between effects of intermittent hypoxia in animal models and in humans remain to be studied.

KEYWORDS: Animal models, chronic obstructive pulmonary disease, high altitude, obstructive sleep apnoea syndrome, pulmonary circulation, remodelling

I n 1946 VON EULER and VON LILJESTRAND [1] from the Karolinska Institute in Stockholm published results of their experiments on the effects of various interventions on pulmonary arterial pressure (PAP), performed in cats. One of the interventions applied consisted of giving experimental animals hypoxic mixtures to breathe. Breathing of a hypoxic mixture (10.5\% of oxygen) resulted in an acute increase in PAP. PAP quickly normalised once the experimental animals were given atmospheric air to breathe. VON EULER and VON LILJESTRAND [1] were the first to demonstrate that the reaction of pulmonary arteries to hypoxia was the opposite to that observed in the systemic circulation in which hypoxia induces vasodilatation [2]. They also, in the discussion section of the paper, put forward a hypothesis explaining the purpose of the described reaction writing: "It is also required however, that the blood becomes distributed to the different parts of the lung in such a way, that the alveolar air will give off oxygen and take up carbon dioxide $\left(\mathrm{CO}_{2}\right)$ fairly evenly throughout the lungs". They were right. A few years later a concept of ventilation/perfusion relationships in the lung was documented [3].

One year later hypoxic pulmonary vasoconstriction (HPV) was confirmed in healthy man. Investigations were performed in the cardiorespiratory laboratory at Bellevue Hospital, New York, USA directed by A. Cournand and D.W. Richards, Jr. MotLEy et al. [4] performed pulmonary artery catheterisation in five healthy subjects. Mean PAP averaged $13 \mathrm{mmHg}$ whilst subjects were breathing air. During hypoxic
CORRESPONDENCE

J. Zieliński

2nd Dept of Respiratory Medicine

Institute of Tuberculosis and Lung

Diseases

Plocka 26

01-138 Warsaw

Poland

Fax: 48224312454

E-mail: j.zielinski@igichp.edu.pl

Received:

March 302004

Accepted after revision:

August 022004

\section{SUPPORT STATEMENT}

This article is based on a Sadoul

Lecture given by the author on

September 29, 2003, at the annual congress of the European Respiratory Society in Vienna, Austria.

European Respiratory Journal Print ISSN 0903-1936 Online ISSN 1399-3003 
mixture breathing, $10 \%$ of oxygen was given and mean PAP rose considerably to $23 \mathrm{mmHg}$. Cardiac output was measured by the Fick method. During hypoxic exposure pulmonary vascular resistance (PVR) doubled, mainly due to vasoconstriction as there was no significant change in the cardiac output.

Two authors of those two seminal investigations were later awarded the Nobel Prize. U.S. von Euler, together with B. Katz and J. Axelrod, were awarded the Nobel Prize in 1970 for the discovery of noradrenaline. In 1956, A. Cournand received a joint prize together with W. Forssmann and D.W. Richards, Jr. for the introduction of cardiac catheterisation into clinical practice.

\section{HYPOXIC PULMONARY VASOCONSTRICTION AND VASCULAR REMODELLING}

BARER et al. [5] found, in animal experiments, that reduction of the alveolar oxygen pressure to $<70 \mathrm{mmHg}$ elicits strong pulmonary vasoconstriction. HPV is common in mammals. However, there are important interspecies differences in HPV. The rabbit shows almost no reaction to hypoxia. Cattle present the strongest vasoconstriction. In man hypoxic vasoconstriction is weaker than in the rat [6].

There is also great individual variability in HPV among humans. NAEIJE et al. [7] demonstrated that in healthy man, individual HPV varied from almost no reaction to very strong vasoconstriction. LAKS et al. [8] found that, during hypoxic exposure in individual subjects, the increase in mean PAP varied between $2-15 \mathrm{mmHg}$.

After some debate about the site of hypoxic constriction in the pulmonary vascular bed it was demonstrated that hypoxia constricts pulmonary muscular arteries, vessels of $<1 \mathrm{~mm}$ in diameter. [9-12]. Despite many years of extensive investigations, the mechanism of HPV is still under debate. A current theory suggests that reduced oxygen pressure inhibits smooth muscle cell voltage-dependent potassium channels, resulting in membrane depolarisation, the influx of calcium and muscle fibre shortening $[13,14]$. Two such channels, $\mathrm{Kv}_{2}$, and $\mathrm{Kv}_{1.5}$, have been described [15]. In addition to intrinsic smooth muscle cell reactivity to hypoxia, altered endothelium-mediated relaxation of pulmonary arteries involving nitric oxide may also play a role [16]. Also, acidosis enhances HPV [17].

\section{PROLONGED HYPOXIA}

Whilst short exposure to hypoxia causes HPV, prolonged hypoxia results in remodelling of distal branches of pulmonary arteries. Experiments in rats kept in hypoxic conditions showed that new muscle and endothelial cells appear in the walls of pulmonary muscular arteries during the first days of continuous hypoxia [18-21].

Hypertrophy and hyperplasia of the medial muscular coat and intimal hypertrophy, muscularisation and fibrosis, remodel the pulmonary microcirculation. Lengthening of the resistance segment, thickening of the wall and narrowing of the lumen result in a durable increase in PVR and an increase in the right ventricle afterload, leading to pulmonary hypertension $(\mathrm{PH})$ and finally to right ventricular hypertrophy [22].

In man, the character of remodelling is somewhat different than in the rat. Hypertrophy of the circular muscular layer between internal and external elastic laminae is less prominent. More important are changes in the intima. Longitudinal bundles of smooth muscle develop, together with endothelial proliferation, and fibroelastosis [23-26]. Intensive remodelling also takes place in the pulmonary arterioles. In healthy man, the pulmonary arterioles are thin walled vessels without a muscular layer. Prolonged hypoxia leads to muscularisation of the arterioles and the development of intimal changes similar to that observed in the muscular arteries contributing further to the increase in PVR.

\section{INTERMITTENT HYPOXIA IN ANIMAL MODELS}

Several investigations have been performed in rats, evaluating effects of intermittent hypoxia (IH) on pulmonary haemodynamics [27-31]. Severe hypoxia was applied in a hypobaric chamber for 4-8 h·day ${ }^{-1}, 5-7$ days a week, with a total of 13-24 exposures. Oxygen pressure in the inspired air ranged from $56 \mathrm{mmHg}$ [30] to $70 \mathrm{mmHg}$ [31]. The results were fairly uniform. Even the shortest exposure to hypoxia resulted in an increase in right ventricle systolic pressure, and right ventricular weight. Remodelling of pulmonary muscular arteries after IH was similar to that observed in rats exposed to prolonged hypoxia [20, 21, 32, 33].

Another model of $\mathrm{IH}$ studied in animals was mimicking pathophysiology of obstructive sleep apnoea (OSA) by applying rapid changes in the composition of inspired gases. MCGUIRE and BRADFORD [34] exposed experimental rats to consecutive $30 \mathrm{~s}$ periods of severe hypoxia followed by $30 \mathrm{~s}$ of normoxia for $8 \mathrm{~h} \cdot \mathrm{day}^{-1}$ for 5 weeks. During that time, mean PAP increased from $20.7 \pm 6.8$ to $31.3 \pm 7.2 \mathrm{mmHg}(\mathrm{p}<0.01)$ and right ventricular mass index increased from 0.25 to 0.31 $(p<0.05)$ indicating right ventricle hypertrophy.

FAGAN [35] performed similar experiments in mice exposed to $2 \mathrm{~min}$ of hypoxic environment (10\% of oxygen), followed by $2 \mathrm{~min}$ of normoxia, for $8 \mathrm{~h} \cdot \mathrm{day}^{-1}$ for 4 weeks. Right ventricle systolic pressure increased from 30 to $36 \mathrm{mmHg}$ and right ventricle mass index increased from 0.22 to 0.27 . Both changes were significant $(p<0.01)$. FAGAN [35] also found that the number of muscular arterioles in the lung of rats exposed to $\mathrm{IH}$ significantly increased $(\mathrm{p}<0.005)$.

\section{INTERMITTENT HYPOXIA IN COPD PATIENTS}

The development of alveolar hypoxia in chronic obstructive pulmonary disease (COPD) is a long process. It has been noted that at first, alveolar hypoxia may appear during sleep. In normal man sleep induces important changes to breathing. Resetting of the respiratory centre to a higher arterial $\mathrm{CO}_{2}$ tension [36], decreased motor neurone output [37], decreased intercostal muscle activity [38], an increase in airway resistance [39] and decrease in functional residual capacity [40] have been reported. All those changes lead to hypoventilation [41], especially during rapid eye movement sleep [42]. Episodes of alveolar hypoventilation lead to a small decrease in arterial oxygen pressure, with no clinically important effect on oxygen transport.

In patients with COPD, breathing disorders induced by sleep are more pronounced [40, 43-44]. Ventilation/perfusion mismatching, the main mechanism of hypoxaemia in COPD, also increases during sleep [45]. 
Hypoxaemia during sleep in COPD patients was first reported by ROBIN [46] and later confirmed by several authors using an elaborate method of multiple arterial blood sampling [47-49]. The introduction of noninvasive oximetry allowed for the continuous monitoring of arterial blood saturation [50,51]. The appearance and severity of nocturnal arterial blood desaturations have generally been related to the arterial blood gas status during wakefulness [52].

However, it was found that some COPD patients who are normoxaemic during the day develop hypoxaemia during sleep. The prevalence of nocturnal desaturation in COPD patients preserving satisfactory oxygenation while awake was not well established. FLETCHER et al. [53] found nocturnal desaturation in $25 \%$ of 135 COPD patients, defining desaturation as a fall in $\mathrm{Sa}_{1} \mathrm{O}_{2}$ below $90 \%$ for 5 min or more with a nadir of $85 \%$ or lower. LEVI-VALENSI et al. [54] found nocturnal desaturation in 18 out of 40 COPD patients, defining desaturation as spending $>30 \%$ of sleep time in saturation below $90 \%$. It was found that overnight oxygen supplementation prevented nocturnal desaturation episodes [55].

Nocturnal desaturation reflects episodes of alveolar hypoxia. Simultaneous continuous recordings of arterial blood saturation and PAP during sleep in COPD patients showed that desaturation dips coincided with the increase in PAP $[55,56]$.

Contrary to the uniform results of experiments in animals showing that $\mathrm{IH}$ leads to development of $\mathrm{PH}$, the results of studies on the effects of $\mathrm{IH}$ on pulmonary haemodynamics in patients with COPD were rather contradictory. In one study [57], pulmonary haemodynamics were investigated in 16 patients desaturating during sleep and in 10 nondesaturating patients. In both groups mild $\mathrm{PH}$ at rest was found. During steady state exercise, PAP increased significantly more $(\mathrm{p}<0.01)$ in desaturating patients than in nondesaturators.

The authors of another study [58] demonstrated that nocturnal oxygen supplementation in desaturating patients prevented the progression of $\mathrm{PH}$, during a 3-yr follow-up trial. In one multicentre investigation, survival in 169 desaturating and nondesaturating patients not treated with oxygen was analysed [59]. Desaturating patients presented a significantly worse $(\mathrm{p}<0.02)$ survival curve compared to nondesaturators.

More recently, a series of similar investigations were performed in Europe. In the first study [60], 94 COPD patients with diurnal arterial oxygen tension $\left(\mathrm{Pa}_{1} \mathrm{O}_{2}\right)>55 \mathrm{mmHg}$ were divided into 66 desaturating patients and 28 nondesaturators. In both groups mean PAP was slightly $<20 \mathrm{mmHg}$. Also, on exercise, increase in PAP was of the same magnitude in desaturators and nondesaturators.

In the second investigation [61], 76 desaturating COPD patients, spending $>30 \%$ of sleep in saturation below $90 \%$, were divided into two groups. A total of 41 of them received nocturnal oxygen supplementation and 35 served as controls. After 2 yrs of follow-up, changes in PAP were insignificant in both groups.

Also, the survival rate in 68 COPD patients, both desaturators and nondesaturators not treated with oxygen, matched for diurnal $\mathrm{Pa}_{\mathrm{a}} \mathrm{O}_{2}$, FEV1 and followed up for $4 \mathrm{yrs}$, was not significantly different [62].

The differences in the results of those two series of studies could be explained by the different number of investigated patients, their selection and, perhaps, effects of other factors leading to PH in COPD. The patients included in the studies by FLETCHER and colleagues $[57,58]$ presented with mild $\mathrm{PH}$ at entry and some of them with signs of left ventricle dysfunction, whereas patients in the studies by CHAOUAT and colleagues $[60,61]$ presented with borderline PAP.

\section{INTERMITTENT HYPOXIA IN COPD PATIENTS ON LONG-TERM OXYGEN TREATMENT}

Patients with severe COPD and permanent hypoxaemia, treated with domiciliary oxygen, may also experience $\mathrm{IH}$. Such patients usually present with permanent PH. Oxygen should be given continuously, but the majority of patients interrupt oxygen breathing several times a day. SELINGER et al. [63] recorded PAP continuously in COPD patients undergoing long-term oxygen treatment (LTOT). Whilst patients were breathing oxygen, mean PAP was stable, slightly $>30 \mathrm{mmHg}$. Interruption of oxygen administration resulted in a steady increase in mean PAP up to $40 \mathrm{mmHg}$. A simultaneous rise in the calculated driving pressure across the pulmonary vascular bed confirmed that the rise in the PAP was due to pulmonary vasoconstriction.

In severe COPD patients, desaturation may also appear during oxygen breathing. Continuous 24-h pulse oximetry was recorded in COPD patients treated with domiciliary oxygen. Desaturation episodes were observed during some daily activities and during sleep while patients were breathing oxygen [64-67].

It is difficult to assess how those pulmonary vasoconstriction episodes caused either by interruption of oxygen breathing or despite oxygen breathing, affect long-term pulmonary haemodynamics.

ZIELIŃSKI et al. [68] followed-up 95 COPD patients, with very advanced disease, starting on LTOT. Mean oxygen breathing hours was $14.5 \mathrm{~h} \cdot$ day $^{-1}$. Pulmonary artery catheterisation had been performed at entry and repeated every 2 yrs, up to 6 yrs. A small reduction in mean PAP and mean PVR was observed after the first 2 yrs of treatment, followed by stabilisation of mean PAP and of mean pulmonary vascular resistance for the remaining 4 yrs of observation. The mean PAP at entry was $25 \pm 7 \mathrm{mmHg}$ and $26 \pm 6 \mathrm{mmHg}$ at 6 yrs. It seems that breathing oxygen for $14.5 \mathrm{~h} \cdot \mathrm{day}^{-1}$ is sufficient to prevent the progression of $\mathrm{PH}$ in patients undergoing LTOT. Other authors have reported a reduction of PAP after LTOT $[69,70]$. Based on these data it seems that short, intermittent episodes of hypoxia do not aggravate $\mathrm{PH}$ in severe COPD patients.

\section{INTERMITTENT HYPOXIA IN OBSTRUCTIVE SLEEP APNOEA}

OSA is a very common disease, defined as an intermittent repeatable cessation of airflow to the lung due to closure of the airway at a pharyngeal level. Cessation of airflow leads to progressive asphyxia and increased respiratory effort, leading to brief arousal from sleep and restoration of airway patency. The patient then returns to sleep and the sequence of events is 
repeated. In patients with severe OSA, episodes lasting 20-40 s may appear 300-400 times per night. An apnoeic episode results in alveolar hypoxia and HPV. In patients with OSA, large swings of intrathoracic pressure during apnoea greatly affect intravascular PAP. To assess HPV during apnoeic episodes, true transmural PAP has to be measured [71]. HPV is resolved at the resumption of breathing [72].

The first polysomnographic recordings in patients with OSA included monitoring of PAP [73, 74]. Patients with severe OSA demonstrated an increase in PAP during apnoeic episodes.

In early studies assessing pulmonary haemodynamics during the day, based on a limited number of patients with severe OSA, PH was found in the majority of subjects studied [75-77]. However, many of the subjects also presented with signs of COPD and diurnal hypoxaemia. Larger, nonselected groups of OSA patients were collected by WEITZENBLUM [78] and Chaouat [79] of the Strasbourg group. Among 220 consecutive patients with OSA diurnal PH (mean PAP $26 \pm 5.8 \mathrm{mmHg}$ ) was found in $17 \%$. The majority of patients with $\mathrm{PH}$ presented with signs of COPD [79]. CHAOUAT et al. [79] concluded that in the majority of patients, $\mathrm{PH}$ could be explained by diurnal hypoxaemia due to COPD or obesity-induced hypoventilation.

Similar findings have been reported by SANNER et al. [80]. They found $\mathrm{PH}$ in $20 \%$ of OSA patients. Patients with $\mathrm{PH}$ presented with restrictive impairment of ventilatory reserves due to obesity. Permanent hypoventilation in severely obese patients with OSA may be the main cause of development of pulmonary hypertension [81].

HAWRYLKIEWICZ et al. [82] studied 67 patients with severe OSA and 17 patients with OSA complicated by COPD, called the overlap syndrome [83]. In patients with OSA (mean apnoeahypopnoea index $=62 \pm 22$ ) mild $\mathrm{PH}$ (mean $\mathrm{PAP}=$ $24 \pm 3.6 \mathrm{mmHg}$ ) was found in 11 subjects. A total of 56 patients presented with normal PAP (mean $14.2 \pm 2.8 \mathrm{mmHg}$ ). Patients with $\mathrm{PH}$ were younger, more obese and had a higher number of apnoeic episodes than subjects with normal PAP. The overnight arterial blood oxygen saturation was not significantly different between patients with normal PAP and patients with $\mathrm{PH}$, suggesting that the nocturnal desaturation did not play an important role in the development of PH. In contrast to patients with "pure" OSA, among 17 patients with the overlap syndrome, only three subjects had normal PAP $($ mean $=12.3 \pm 3.1 \mathrm{mmHg}$ ) and 14 presented with moderate $\mathrm{PH}$ (mean PAP $=26.8 \pm 5.1 \mathrm{mmHg}$ ).

However, there are a number of studies demonstrating that $\mathrm{PH}$ is rather frequent in patients with OSA. LAKS et al. [84] found $\mathrm{PH}$ in 42 of 100 OSA patients. Patients with $\mathrm{PH}$ were older, had higher $\mathrm{CO}_{2}$ arterial tension $\left(\mathrm{Pa}_{\mathrm{a}} \mathrm{CO}_{2}\right)$, lower arterial oxygen tension and lower FEV1. Such a constellation of signs suggests that some of those patients belonged to the group of the overlap syndrome.

Recently, BADY et al. [85] found PH in 12 out of 44 patients with "pure" OSA. Patients with PH had significantly lower daytime arterial oxygen tension, higher daytime $\mathrm{CO}_{2}$ tension, more severe nocturnal hypoxaemia, and higher body mass index (BMI). Stepwise multiple regression analysis showed that mean PAP was positively correlated with BMI and negatively with $\mathrm{Pa}_{\mathrm{a}} \mathrm{O}_{2}$. Also, SAJKOV et al. [86] reported $\mathrm{PH}$ in 12 out of 27 patients with OSA. His results should be cautiously analysed, as in that study PAP was measured indirectly using the echoDoppler method.

The large differences in the literature concerning the prevalence of $\mathrm{PH}$ in patients with OSA may perhaps be related to behavioural factors [87-89] genetic predisposition [6, 7, 90], severity of obesity [91] or left ventricle dysfunction [80].

\section{SHORT-TERM HYPOXIA AT HIGH ALTITUDE}

At sea level, the oxygen pressure in the inspired air $\left(\mathrm{Pi}_{\mathrm{i}} \mathrm{O}_{2}\right)$ is equal to $150 \mathrm{mmHg}$. At an elevation of $3,000 \mathrm{~m}, \mathrm{Pi}_{1} \mathrm{O}_{2}$ is one third lower than at sea level. People born and living in Leadville, Colorado, USA, 3,100 m above sea level (ASL), have mild $\mathrm{PH}$ (mean $\mathrm{PAP}=24 \mathrm{mmHg}$ ) [92]. At the elevation of $5,000 \mathrm{~m}, \mathrm{Pi}, \mathrm{O} 2$ equals $75 \mathrm{mmHg}$. Aimara and Ketchua Indians inhabiting the high altitude plateau in the Andes, Bolivia and Peru living at elevations $\sim 4000 \mathrm{~m}$ ASL, have moderate $\mathrm{PH}$ (mean PAP $=27-28 \mathrm{mmHg}$ ) [93-95]. During a 6-week simulated ascent to Mount Everest, Nepal, in a hypobaric chamber $\left(P \mathrm{i}, \mathrm{O}_{2}\right.$ at the summit $\left.=43 \mathrm{mmHg}\right)$, healthy volunteers developed moderate $\mathrm{PH}$ (mean $\mathrm{PAP}=34 \pm 3 \mathrm{mmHg}$ ), partly unresponsive to oxygen breathing [96].

Hypertrophy of the muscular layer in pulmonary muscular arteries and arterioles is a prominent feature of remodelling in people permanently living at high altitude [97] in distinction to changes observed in patients with COPD [25]. It may be hypothesised that high altitude hypoxia-induced structural changes in pulmonary arteries develop rather rapidly in normal man. The only partial reduction of $\mathrm{PH}$ during oxygen breathing in subjects exposed to 6 weeks of hypoxia simulating ascent to Mount Everest implies that there were structural changes in the pulmonary arteries in addition to vasoconstriction [96]. Indian soldiers deployed in the very high mountains ( $\sim 6,000 \mathrm{~m}$ ASL) for 18 weeks developed signs of right heart failure. Pulmonary artery catheterisation performed a few days after the descent to low altitude showed that the soldiers still had mild $\mathrm{PH}$, mean $\mathrm{PAP}=26 \mathrm{mmHg}$. $\mathrm{PH}$ completely resolved after 12 weeks of recovery at lowland [98].

\section{SHIFT WORK AT HIGH ALTITUDE}

In the last 20 yrs a new type of exposure to high altitude has developed. To assure uninterrupted functioning of high altitude mines and telescope stations, commuting of the working staff between low and high altitude has become more and more frequent. The pattern of commuting varies from hours to weeks at high altitude balanced by an equal time at sea level or moderate altitude. The medical and physiological consequences of indefinitely repeated exposure to high altitude are poorly understood $[99,100]$.

There is very little data concerning effects of intermittent hypoxia of high altitude on pulmonary haemodynamics. One investigation was performed in the Collahuasi copper mine, Chile [101]. Miners working there spend 7 days at altitude ranging from $3,800-4,600 \mathrm{~m}$ ASL. The working shift is followed by a 7-day holiday at sea level. A total of 29 miners, mean age 25 yrs, were followed up for 2.5 yrs. One of the variables studied was PAP, assessed at sea level by an echocardiographic method. Initial measurement showed 
normal PAP. There was no increase in the PAP measured four times during the 31 months of follow-up. At each investigation, after initial measurements were taken whilst breathing air, subjects were asked to breathe a hypoxic mixture, mimicking conditions at the level of the mine. Pulmonary vasoconstriction of fairly constant magnitude was observed.

Another study on pulmonary haemodynamics in miners working in the gold mine situated in the Tien-Shan Mountains in Kyrgyzstan was recently published by SARYBAEV et al. [102]. A total of 26 healthy Caucasian males, mean age $42 \pm 9$ yrs were studied. They had been working at the mine for 4 weeks at elevations ranging from 3,700-4,200 m ASL followed by 4-week holidays at low altitude. Pulmonary haemodynamics were assessed by the echocardiographic method. The first examination was performed at low altitude on return from holidays. The mean calculated PAP ranged from $10-18 \mathrm{mmHg}$ (mean $=14.7 \pm 2.7 \mathrm{mmHg}$ ). Second measurements were performed at the end of the 4-week working shift at 3,700 $\mathrm{m}$ ASL, $\mathrm{P}_{\mathrm{i}, \mathrm{O}_{2}}=89 \mathrm{mmHg}$. The individual increase in mean PAP was very variable, ranging between $3-19 \mathrm{mmHg}$ (mean PAP $=25.8 \pm 8.3 \mathrm{mmHg}$ ). Ten subjects with the strongest hypoxic vasoconstriction, with an increase in PAP under hypoxic condition of $>10 \mathrm{mmHg}$, were selected and followed up for the next 2 yrs.

Consecutive measurements were performed yearly at high altitude at the end of the working shift. Initially in those 10 subjects, mean PAP at low altitude was $15 \pm 2 \mathrm{mmHg}$ and increased to $28 \pm 4 \mathrm{mmHg}$ at high altitude. Mean PAP during the next 2 yrs remained unchanged. During the last measurements a hyperoxic test was performed. Subjects received $100 \%$ oxygen to breathe for $30 \mathrm{~min}$. The mean PAP fell to $18 \pm$ $2.7 \mathrm{mmHg}$, confirming that $\mathrm{PH}$ was induced by HPV and was reversible.

The results of these two studies suggested that prolonged exposure to intermittent high altitude hypoxia at elevations $\sim 4,000 \mathrm{~m}$ ASL did not lead to permanent PH, contrary to permanent dwellers at high altitude who, at similar altitudes, suffer from moderate $\mathrm{PH}$.

However, there is an exception to that rule. There is one ethnic group living in the high mountains who do not develop $\mathrm{PH}$. Tibetans, by a long process of adaptation, are almost free from hypoxic pulmonary vasoconstriction and hypertension [103, 104].

\section{WHY ARE THERE DIFFERENCES IN EFFECTS OF INTERMITTENT HYPOXIA IN ANIMALS AND IN HUMANS?}

The discrepancy between the results of animal experiments and those of clinical studies in humans is difficult to explain. Donald Heath, a researcher with great experience in the field of pulmonary circulation at sea level and at high altitude, suggested that the rat is a bad model of hypoxic PH [105]. In rats, muscularisation of pulmonary arteries is the most prominent feature of hypoxic remodelling, whereas in man, endothelial proliferation and fibroelastosis play a crucial role.

Also, hypoxia applied in animal experiments has been much more severe than the hypoxia developing in the disease state in humans. This could result in a different severity of vasoconstriction and remodelling. In animals with normal lungs alveolar hypoxia is fairly uniform, contrary to uneven distribution of inspired air in patients with COPD or OSA. This may result in large regional differences in hypoxic pulmonary vasoconstriction, and in remodelling.

It is also possible that an episode of hypoxic pulmonary vasoconstriction in humans must last a certain time before it initiates reactions leading to arterial wall remodelling [106]. Another cause of discrepancy may be related to an individual susceptibility to the hypoxic stimulus [107].

\section{CONCLUSIONS}

In animal models, intermittent severe hypoxia leads to the development of pulmonary hypertension irrespective of hypoxia/normoxia intervals. Intermittent hypoxia in man seems to exert only a small, probably clinically unimportant, effect on pulmonary haemodynamics.

\section{ACKNOWLEDGEMENTS}

The author would like to thank S. Fronczak, librarian at the Institute of Tuberculosis and Lung Diseases for invaluable help in the literature search, and A. Dymont for secretarial help.

\section{REFERENCES}

1 von Euler US, von Liljestrand G. Observations on the pulmonary arterial blood pressure in the cat. Acta Physiol Scand 1946; 12: 301-320.

2 Kornet PI. Circulatory adaptations to hypoxia. Physiol Rev 1959; 39: 687-730.

3 Rahn H. A concept of mean alveolar air and the ventilation-bloodflow relationships during pulmonary gas exchange. Am J Physiol 1949; 158: 21-30.

4 Motley HL, Cournand A, Werko L, Himmelstein A, Dresdale D. The influence of short periods of induced acute anoxia upon pulmonary artery pressure in man. Am J Physiol 1947; 150: 315-320.

5 Barer GR, Howard P, Shaw JW. Stimulus-response curves for the pulmonary vascular bed to hypoxia and hypercapnia. J Physiol (London) 1970; 211: 139-155.

6 Reeves JT, Wagner WW Jr, McMurtry IF, et al. Physiological effects of high altitude on the pulmonary circulation. In: D. Robertshaw, ed. International Review of Physiology. Environmental Physiology III. Vol. 20. University Park Press, Baltimore, 1979; Chap. 6, pp. 289 310.

7 Naeije R, Melot Ch, Mols P, Hallemans R. Effects of vasodilators on hypoxic pulmonary vasoconstriction in normal man. Chest 1982; 82: 404-410.

8 Laks L, Lehrhaft B, Grunstein R, Sullivan CE. Pulmonary artery pressure response to hypoxia in sleep apnoea. Am J Respir Crit Care Med 1997; 155: 193-198.

9 Kato M, Staub NC. Response of small pulmonary arteries to unilobar hypoxia and hypercapnia. Circ Res 1966; 19: 426-440.

10 Bergofsky EH, Haas F, Porcelli R. Determination of the sensitive vascular sites from which hypoxia and hypercapnia elicit rises in pulmonary arterial pressure. Fed Proc 1968; 27: 1405-1420. 
11 Glazier JB, Murray JF. Sites of pulmonary vasomotor reactivity in the dog during alveolar hypoxia and serotonin and histamine infusion. J Clin Invest 1971; 50: 2550-2558.

12 Shirai M, Sada K, Ninomiya I. Effects of regional alveolar hypoxia and hypercapnia on pulmonary arteries in cat. J Appl Physiol 1986; 61: 440-448.

13 Weir EK, Archer SL. The mechanism of acute hypoxic pulmonary vasoconstriction: the tale of two channels. FASEB J 1995; 9: 183-189.

14 Post JM, Hume JR, Archer SL, Weir EK. Direct role of potassium channel inhibition in hypoxic pulmonary vasoconstriction. Am J Physiol 1992; 262: C882-C890.

15 Archer SL, Sonil E, Dinh-Xuan AT, et al. Molecular identification of the role of voltage-gated $\mathrm{K}+$ channels, $\mathrm{Kv}$ 1.5 and $\mathrm{Kv} 2.1$, in hypoxic pulmonary vasoconstriction and control of resting membrane potential in rat pulmonary artery myocytes. J Clin Invest 1998; 101: 2319-2330.

16 Dinh-Xuan AT, Higgenbottam TW, Clelland CA, et al. Impairment of endothelium dependent pulmonary artery relaxation in chronic obstructive pulmonary disease. N Engl J Med 1991; 324: 1539-1547.

17 Lloyd TC Jr. Influence of blood $\mathrm{pH}$ on hypoxic pulmonary vasoconstriction. J Appl Physiol 1966; 21: 358-364.

18 Meyrick B, Read L. The effect of continued hypoxia on rat pulmonary arterial circulation: an ultra structural study. Lab Invest 1978; 38: 188-200.

19 Meyrick B, Reid L. Hypoxia and incorporation of ${ }^{3} \mathrm{H}-$ thymidine by cells of the rat pulmonary arteries and alveolar wall. Am J Pathol 1979; 96: 51-70.

20 Meyrick B, Reid L. Hypoxia - induced structural changes in the media and adventitia of rat hilar pulmonary artery and their regression. Am J Pathol 1980; 100: 151-178.

21 Fung YC, Lin SQ. Changes of zero-stress state of rat pulmonary arteries in hypoxic hypertension. J Appl Physiol 1991; 70: 2455-2470.

22 Kay JM. Effects of intermittent normoxia on chronic pulmonary hypertension, right ventricular hypertrophy, and polycythemia in rats. Am Rev Respir Dis 1980; 121: 993-1001.

23 Hasleton PS, Heath D, Brewer DB. Hypertensive pulmonary vascular disease in states of chronic hypoxia. J Path Bacteriol 1968; 98: 431-440.

24 Magee F, Wright JL, Wiggs BR, Pare PD, Hogg JC. Pulmonary vascular structure and function in chronic obstructive pulmonary disease. Thorax 1988; 43: 183-189.

25 Wilkinson M, Langhorne CA, Heath D, Barer GR, Howard P. A pathophysiological study of 10 cases of hypoxic cor pulmonale. Q J Med 1988; 66: 65-85.

26 Calverley PM, Howatson R, Flenley DC, Lamb D. Clinicopathological correlations in cor pulmonale. Thorax 1992; 47: 494-498.

27 Widimsky J, Urbanova D, Ressl J, Oštadál B, Pelouch V, Procházka J. Effect of intermittent altitude hypoxia on the myocardium and lesser circulation in the rat. Cardiovasc Res 1973; 7: 798-808.

28 McGrath JJ, Procházka J, Pelouch V, Oštádal B. Physiological responses of rats to intermittent high-altitude stress: Effects of age. J Appl Physiol 1973; 34: 289-293.
29 Ressl J, Urbanová D, Widimsky J, Oštádal B, Pelouch V, Procházka J. Reversibility of pulmonary hypertension and right ventricular hypertrophy induced by intermittent high altitude hypoxia in rats. Respiration 1974; 31: 38-46.

30 Sizemore DA, McIntyre TW, Van Liere EJ, Wilson MF. Regression of altitude-produced cardiac hypertrophy. J Appl Physiol 1973; 35: 518-521.

31 Nattie EE, Bartlett D Jr, Johnson K. Pulmonary hypertension and right ventricular hypertrophy caused by intermittent hypoxia and hypercapnia in the rat. $A m$ Rev Respir Dis 1978; 118: 653-658.

32 Herget J, Suggett AJ, Leach E, Barer GR. Resolution of pulmonary hypertension and other features induced by chronic hypoxia in rats during complete and intermittent hypoxia. Thorax 1978; 33: 468-473.

33 Kay JM, Suyama KL, Keane PM. Effect of intermittent normoxia on muscularization of pulmonary arterioles induced by chronic hypoxia in rats. Am Rev Respir Dis 1981; 123: 454-458.

34 McGuire M, Bradford A. Chronic intermittent hypercapnic hypoxia increases pulmonary arterial pressure and hematocrit in rats. Eur Respir J 2001; 18: 279-285.

35 Fagan AK. Physiological and genomic consequences of intermittent hypoxia. Selected contribution: Pulmonary hypertension in mice following intermittent hypoxia. J Appl Physiol 2001; 90: 2502-2507.

36 Berthon-Jones M, Sullivan CE. Ventilation and arousal responses to hypercapnia in normal sleeping adults. J Appl Physiol 1984; 57: 59-67.

37 Orem J. Medullary respiratory neuron activity: relationship to tonic and phasic REM sleep. J Appl Physiol 1980; 48: 54-65.

38 Millman RP, Knight H, Kline LR, et al. Changes in compartmental ventilation in association with eye movements during REM sleep. J Appl Physiol 1988; 65: 1196-1202.

39 Lopes JM, Tabachnik E, Muller NL, et al. Total airway resistance and respiratory muscle activity during sleep. J Appl Physiol 1983; 54: 773-777.

40 Hudgel DW, Martin RJ, Capehart M, Johnson B, Hill P. Contribution of hypoventilation to sleep oxygen desaturation in chronic obstructive pulmonary disease. J Appl Physiol 1983; 55: 669-677.

41 Douglas NJ, White DP, Pickett CK, Weil JV, Zwillich CW. Respiration during sleep in normal man. Thorax 1982; 37: 840-844.

42 Gould GA, Gugger M, Molloy J, Tsara V, Skiuiro CM, Douglas NJ. Breathing pattern and eye movement density during REM sleep in man. Am Rev Respir Dis 1988; 138: 874-877.

43 Wynne JW, Block AJ, Hemenway J, Hunt LA, Flick MR. Disordered breathing and oxygen desaturation during sleep in patients with chronic obstructive lung disease (COLD). Am J Med 1979; 66: 573-579.

44 Becker HF, Piper AJ, Flynn WE, et al. Breathing during sleep in patients with nocturnal desaturation. Am J Respir Crit Care Med 1999; 159: 112-118.

45 Catterall JR, Calverley PMA, MacNee W, et al. Mechanism of transient nocturnal hypoxemia in hypoxic 
chronic bronchitis and emphysema. J Appl Physiol 1985; 59: 1698-1703.

46 Robin ED. Some interrelations between sleep and disease. Arch Intern Med 1958; 102: 669-675.

47 Pierce AK, Jarrett CE, Werkle G, et al. Respiratory function during sleep in patients with chronic obstructive lung disease. J Clin Invest 1966; 45: 631-636.

48 Radwan L, Dufmats H. Variations of arterial oxygen and carbon dioxide tension during 24 hours in chronic respiratory insufficiency. Scand J Respir Dis 1974; 55: 99-104.

49 Koo KW, Sax DS, Snider GL. Arterial blood gases and pH during sleep in chronic obstructive pulmonary disease. Am J Med 1975; 58: 663-670.

50 Flick MR, Block AJ. Continuous in vivo monitoring of arterial oxygenation in chronic obstructive lung disease. Ann Intern Med 1977; 86: 725-730.

51 Douglas NJ, Calverley PMA, Leggett RJE, Brash HM, Flenley DC, Brezinova V. Transient hypoxaemia during sleep in chronic bronchitis and emphysema. Lancet 1979; 1: 1-4.

52 McKeon JL, Muree-Allan K, Sanders NA. Prediction on oxygenation during sleep in patients with chronic obstructive lung disease. Thorax 1988; 43: 312-317.

53 Fletcher EC, Miller J, Divine GW, Fletcher JG, Miller T. Nocturnal oxyhaemoglobin desaturation in COPD patients with arterial oxygen tension above $60 \mathrm{mmHg}$. Chest 1987; 92: 604-608.

54 Levi-Valensi P, Weitzenblum E, Rida Z, et al. Sleeprelated oxygen desaturation and daytime pulmonary haemodynamics in COPD patients. Eur Respir J 1992; 5: 301-305.

55 Fletcher EC, Levin DC. Cardiopulmonary hemodynamics during sleep in subjects with chronic obstructive pulmonary disease: the effect of short- and long-term oxygen. Chest 1984; 85: 6-14.

56 Weitzenblum E, Muzet A, Ehrhart M, Ehrhart J, Sautegeau A, Weber L. Variations nocturnes des gaz du sang et de la pression arterielle pulmonaire chez les bronchitiques insuffisants respiratoires. Nouv Presse Med 1982; 11: 1119-1122.

57 Fletcher EC, Luckett RA, Miller T, Fletcher JG. Exercise hemodynamics and gas exchange in patients with chronic obstruction pulmonary disease, sleep desaturation and a daytime PaO2 above $60 \mathrm{~mm} \mathrm{Hg}$. Am Rev Respir Dis 1989; 140: 1237-1245.

58 Fletcher EC, Luckett RA, Goodnight-White S, Miller CC, Qian W, Costarangos-Galarza C. A double blind trial of nocturnal supplemental oxygen for sleep desaturation in patients with chronic obstructive pulmonary disease and a daytime $\mathrm{PaO}_{2}$ above $60 \mathrm{~mm} \mathrm{Hg}$. Am Rev Respir Dis 1992; 145: 1070-1076.

59 Fletcher EC, Donner CF, Midgren B, et al. Survival in COPD patients with a daytime $\mathrm{PaO}_{2}>60 \mathrm{~mm} \mathrm{Hg}$ with and without nocturnal oxyhaemoglobin desaturation. Chest 1992; 101: 649-655.

60 Chaouat A, Weitzenblum E, Kessler R, et al. Sleep-related $\mathrm{O} 2$ desaturation and daytime pulmonary haemodynamics in COPD patients with mild hypoxaemia. Eur Respir J 1997; 10: 1730-1735.
61 Chaouat A, Weitzenblum E, Kessler R, et al. A randomised trial of nocturnal oxygen therapy in chronic obstructive pulmonary disease patients. Eur Respir J 1999; 14: 1002-1008.

62 Chaouat A, Weitzenblum E, Kessler R, et al. Outcome of COPD patients with daytime hypoxaemia with or without sleep-related oxygen desaturation. Eur Respir J 2001; 17: 848-855.

63 Selinger SR, Kennedy TP, Buescher P, et al. Effect of removing oxygen from patients with chronic obstructive pulmonary disease. Am Rev Respir Dis 1987; 136: 85-91.

64 Estopa RM, Monasterio C, Escarrabill J. Daily life desaturations in COPD patients on LTOT: International Oxygen Club Multicentre European Study. Monaldi Arch Chest Dis 1993; 48: 426-428.

65 Śliwinski P, Lagosz M, Gorecka D, Zielinski J. The adequacy of oxygenation in COPD patients undergoing long-term oxygen therapy assessed by pulse oximetry at home. Eur Respir J 1994; 7: 274-278.

66 Morrison D, Skwarski KM, MacNee W. The adequacy of oxygenation in patients with hypoxic chronic obstructive pulmonary disease treated with long-term domiciliary oxygen. Respir Med 1997; 91: 287-291.

67 Abdulla J, Godtfredsen N, Pisinger C, Wennike P, Tonnesen P. Adequacy of oxygenation in a group of Danish patients with COPD on long-term oxygen therapy. Monaldi Arch Chest Dis 2000; 55: 279-282.

68 Zielinski J, Tobiasz M, Hawryłkiewicz I, Sliwinski P, Pałasiewicz G. Effects of long-term oxygen therapy on pulmonary hemodynamics in COPD patients. Chest 1998; 113: $65-70$.

69 Weitzenblum E, Oswald M, Apprill M, Ratomaharo J, Kessler R. Evolution of physiologic variables in patients with chronic obstructive pulmonary disease before and during long-term oxygen therapy. Respiration 1991; 58: 126-131.

70 Nocturnal Oxygen Therapy Trial Group. Continuous or nocturnal oxygen therapy in hypoxemic chronic obstructive lung disease: a clinical trial. Ann Intern Med 1980; 93: 391-398.

71 Marrone O, Milone F, Ferrara G, Romano L, Bellia V. Transmural pulmonary artery pressure during CPAP in obstructive sleep apnoea syndrome. Eur Respir J 1990; 3, Suppl. 11, 544s-545s

72 Marrone O, Bellia V, Ferrara G, et al. Transmural pressure measurements. Importance in the assessment of pulmonary hypertension in obstructive sleep apnoeas. Chest 1989; 95: 338-342.

73 Coccagna G, Mantovani M, Brignani F, Parchi C, Lugaresi E. Continuous recording of the pulmonary and systemic arterial pressure during sleep in syndromes of hypersomnia with periodic breathing. Bull Physiopathol Respir 1972; 8: 1159-1172.

74 Lonsdorfer J, Meunier-Carus J, Lampert-Benignus E, et al. Haemodynamic and respiratory aspects of the Pickwickian syndrome. Bull Physiopathol Respir 1972; 8: 1181-1192

75 Tilkian AG, Guilleminault C, Schroeder JS, Lehrman KL, Simmons FB, Dement WC. Haemodynamics in sleepinduced apnoea studies during wakefulness and sleep. Ann Intern Med 1976; 85: 714-719. 
76 Schroeder JS, Motta J, Guilleminault C. Hemodynamic studies in sleep apnoea. In: Guilleminault C, Dement WC, eds. Sleep apnoea syndromes. New York, Alan Liss, 1978; pp. 177-196.

77 Bradley TD, Rutherford R, Grossman RF, et al. Role of daytime hypoxemia in the pathogenesis of right heart failure in the obstructive sleep apnoea syndrome. Am Rev Respir Dis 1985; 131: 835-839.

78 Weitzenblum E, Krieger J, Apprill M, et al. Daytime pulmonary hypertension in patients with obstructive sleep apnoea syndrome. Am Rev Respir Dis 1988; 138: 345-349.

79 Chaouat A, Weitzenblum E, Krieger J, Oswald M, Kessler R. Pulmonary hemodynamics in the obstructive sleep apnoea syndrome. Results in 220 consecutive patients. Chest 1996; 109: 380-386.

80 Sanner BM, Doberaurer C, Konermann M, Sturm A, Zidek W. Pulmonary hypertension in patients with obstructive sleep apnoea syndrome. Arch Intern Med 1997; 157: 2483-2487.

81 Kessler R, Chaouat A, Schinkiewitch P, et al. The obesity hypoventilation syndrome revisited. A prospective study of 34 consecutive cases. Chest 2001; 120: 369-376.

82 Hawryłkiewicz I, Sliwinski P, Gorecka D, Plywaczewski R, Zielinski J. Effects of nocturnal hypoxaemia on development of hypoxic pulmonary hypertension. Monaldi Arch Chest Dis 2005 (in press).

83 Flenley DC. Sleep in chronic obstructive lung disease. Clin Chest Med 1985; 6: 651-661.

84 Laks L, Lehrhaft B, Grunstein RR, Sullivan CE. Pulmonary hypertension in obstructive sleep apnoea. Eur Respir J 1995; 8: 537-541.

85 Bady E, Achkar A, Pascal S, Orvoen-Frija E, Labaan JP. Pulmonary hypertension in patients with sleep apnoea syndrome. Thorax 2000; 55: 934-939.

86 Sajkov D, Cowie RJ, Thornton AT, Espinoza HA, McEvoy RG. Pulmonary hypertension and hypoxemia in obstructive sleep apnoea syndrome. Am J Respir Crit Care Med 1994; 149: 416-422.

87 Stradling JR. Obstructive sleep apnoea: definitions, epidemiology and natural history. Thorax 1995; 50: 683-689.

88 Taasan VC, Block AJ, Boysen PG, Wynne JW, White C, Lindsey S. Alcohol increases sleep apnoea and oxygen desaturation in asymptomatic men. Am J Med 1981; 71: 240-245.

89 Chan CS, Grunstein RR, Bye PTP, Woolcock AJ, Sullivan CE. Obstructive sleep apnoea with severe chronic airflow limitation. Am Rev Respir Dis 1989; 140: 1274-1278.

90 Melot C, Naeije R, Hallemans R, Lejeune P, Mols P. Hypoxic pulmonary vasoconstriction and pulmonary gas exchange in normal man. Respir Physiol 1987; 68: 11-27.

91 Laaban JP, Cassuto D, Orvoen-Frija E, et al. Cardiorespiratory consequences of sleep apnoea syndrome in patients with massive obesity. Eur Respir J 1998; 11: 20-27.
92 Grover RF, Wagner WW, McMurtry IF, Reeves JT. Pulmonary circulation. In: Shepherd JT, Abbound FM, eds: Handbook of Physiology. The Cardiovascular System. Peripheral Circulation and Organ Blood Flow. Bethesda, Am Physiol Soc 1985; sect. 2, vol. III, part 1, chapt. 4, pp. 103-136.

93 Penaloza D, Sime F, Banchero N, Gamboa R, Cruz J, Marticorena E. Pulmonary hypertension in healthy man born and living at high altitudes. Am J Cardiol 1963; 11: 150-157.

94 Sime F, Banchero N, Penaloza D, Gamboa R, Cruz J, Marticorena E. Pulmonary hypertension in children born and living at high altitudes. Am J Cardiol 1963; 11: 143-148.

95 Hultgren H, Kelly J, Miller H. Pulmonary circulation in acclimatized man at high altitude. J Appl Physiol 1965; 20: 233-238.

96 Groves BM, Reeves JT, Sutton JR, et al. Operation Everest II: Elevated high-altitude pulmonary resistance unresponsive to oxygen. J Appl Physiol 1987; 63: 521-530.

97 Wagenvoort CA, Wagenvoort N. Hypoxic pulmonary vascular lesions in man at high altitude and in patients with chronic respiratory disease. Pathol Microbiol 1973; 39: 276-282.

98 Anand IS, Malhotra RM, Chandrashekhar Y, et al. Adult mountain sickness - a syndrome of congestive heart failure in man at very high altitude. Lancet 1990; 335: 561-565.

99 Powell FL, Garcia N. Physiological effects of intermittent hypoxia. High Alt Med Biol 2000; 1: 125-133.

100 West JB. Intermittent exposure to high altitude. High Alt Med Biol 2002; 3: 141-143.

101 Richalet JP, Donoso MV, Jimenez D, et al. Chilean miners commuting from sea level to $4500 \mathrm{~m}$ : a prospective study. High Alt Med Biol 2002; 3: 159-166.

102 Sarybaev AS, Palasiewicz G, Usupbaeva DA, et al. Effects of intermittent exposure to high altitude on pulmonary haemodynamics: A prospective study. High Alt Med Biol 2003; 4: 455-463.

103 Groves BM, Droma T, Sutton JR, et al. Minimal hypoxic pulmonary hypertension in normal Tibetans at 3,658 m. J Appl Physiol 1993; 74: 312-318.

104 Yang JS, He ZQ, Zhai HY, et al. A study of the changes of pulmonary arterial pressure in healthy people in the plains and at high altitude under exercise load. Clin J Cardiol 1987; 15: 39-41.

105 Heath D. The rat is a poor animal model for the study of human pulmonary hypertension. Cardioscience 1992; 3: 1-6.

106 Tozzi CA, Poiani GJ, Harangozo AM, Boyd CD, Riley DJ. Pressure induced connective tissue synthesis in pulmonary artery segments is dependent on intact endothelium. J Clin Invest 1989; 84: 1005-1012.

107 Weitzenblum E, Chauat A. Hypoxic pulmonary hypertension in man: what minimum daily duration of hypoxaemia is required? Eur Respir J 2001; 18: 251-253. 